\title{
The Civil liability of Doctor Comparative Study between English and Kuwaiti Laws
}

\author{
By \\ Dr. Thafar Alhajri \\ Assistant Professor
}

Saad Al-Abdullah Academy for Security Sciences,

Department of Law, Kuwait 
Vol. 59, Apeil. 2016

Dr. Thafar Alhajri

مجلتّ البحوث القانونيت والإقتصاديت 


\section{Introduction:}

Civil liability is made up of two principal parts: tortious liability and contractual liability. Contractual liability arises as a result of non-performance of the contract. Claims producing from breach of contract relate to the failure of one of the parties to perform their duties under a contract.

A tort is a form of civil wrong. ${ }^{1}$ Underhill $^{2}$ describes it as an act or omission which is not authorised by law, and independently of contract. Winfield defines a tort or tortious liability that “tortious liability arises from the breach of a duty primarily fixed by law; this duty is towards persons generally and its breach is redressible by an action for un liquidated damages." 3 So, the liability for negligence is the damage suffered by one person owing to another person's fault. ${ }^{4}$

${ }^{1}$ The word 'tort' is derived from Civil Law which Kuwaiti Law enforces.

${ }^{2}$ Underhill, Law of torts, (15 ${ }^{\text {th }}$ ed, 1964), p. 4.

${ }^{3}$ W. V. H. Rogers, Winfield \& Jolowicz on Tort, $\left(17^{\text {th }}\right.$ ed, Sweet \& Maxwell, London 2006), p 5.

4 Hussein Amer, Abdulraheem Amer, Civil Liability, Contractual and negligence liability, (2 ${ }^{\text {nd }}$ ed, Dar Almaaref, Egypt, 1979), p. 11. 
The practice of medical profession defines the origin of relationship between doctors and patients. Accordingly, the professional liability of doctors is defined by the rules of contract and tort. In practice most claims for medical malpractice are brought in tort.

The contract and tort are the basis of doctor's liability. Therefore, this article will examine the contractual liability of doctor first, and then the tort of negligence will be addressed.

\section{Conditions and elements of the contractual liability of the doctor}

This section will examine when contractual liability arises and which contractual promises are considered as being unbreached. It will also consider whether contractual fault contains only a breach of the contractual obligation or whether it extends to any damage arising from the breach of contract.

For contractual liability to be produced, it must be shown that a valid contract between the contractors exists and that the breach of this contract is the cause of the damage. 


\subsection{Conditions of the contractual liability of the doctor}

There are three conditions giving cause to contractual liability. These are examined below:

\subsubsection{The contract must have existed and valid}

Obviously, if there is no contract, there is no contractual liability. ${ }^{1}$ The contract must be valid in order for the liability to be considered contractual liability. A party of the contract can ask to set aside the contract if it is void or voidable. ${ }^{2}$ A void contract is strictly a contradiction in terms ${ }^{3}$ and it is different from a voidable contract. A voidable contract remains alive until and unless it is vitiated by an order of defeasance made by the court at the request of a party seeking to terminate it. ${ }^{4}$

${ }^{1}$ Izzedine Aldnasouri, Abdulhamid Alshawarbi, Civil Liability in the Light of Doctrine and Jurisprudence, (first part, Manshat Almaaref, Alexandria, 2004), p 494. See also Hussein Amer, Abdulraheem Amer, Civil Liability, Contractual and Negligent Liability, ( $2^{\text {nd }}$ ed), Dar Almaaref, Egypt, 1979. p 38.

${ }^{2}$ Hussein Amer, Abdulraheem Amer, Supra 4. p 47.

${ }^{3}$ Islington LBC v Uckac [2006] 1 W. L. R. 1303, CA. It because never came in existence.

${ }^{4}$ Ibid. 
The question arises here, is there a contract between the patients, treated under the NHS, and their doctors. In the Canadian case of Pittman Estate v. Bain, ${ }^{1}$ the hospital arguing that payment to the hospital for the patient's treatment coming not from the patient but from the government through general health care strategies. So, there was no contract with the patient and there was no consideration. However, it was held that patients give indirect or non-monetary consideration for their hospital care. The hospital is operated by patients' contribution indirectly through health premiums and taxes. The hospital receives also benefit by providing it with patients. Lang J. said that the plaintiff agreed to confer the benefit on the hospital encounter get treatment at the hospital. This was satisfactory consideration to advocate a contract between the patient and the hospital. ${ }^{2}$ The courts are understandably reluctant to draw a sharp distinction between the contractual rights of patients receiving private medical treatment and their contractual rights under the NHS. ${ }^{3}$ The doctor, providing

${ }^{1}$ (1994) 112 D.L.R. (4 $\left.{ }^{\text {th }}\right) 257$ (Ont.Ct.,Gen.Div.).

${ }^{2}$ Ibid, at p. 334.

${ }^{3}$ Hotson v. East Berkshire HA [1987] 1 All E.R. 210, 216. Sir John Donaldson M.R said that "Equally I am quite unable to detect any rational basis for a state of the law, if such it be, whereby in identical circumstances Dr. A who = 
private treatment, owes a concurrent obligation in tort to the patient. The patient has a right to sue in both contract and tort. However, the doctor's contractual duties are generally no larger than the obligations owed in tort. ${ }^{1}$

\subsubsection{The contract must be signed by the causative party and injured party}

The contract must be signed by the causative party and the injured party for the liability to be contractual liability. The consequences of the contract only apply to its parties. ${ }^{2}$ It is obvious that the doctor and patient are parties of the contract. Therefore, each one can sue another according to breach the contract concluded between them.

= treats a patient under the National Health Service, and whose liability therefore falls to be determined in accordance with the law of tort, should be in a different position from Dr. B. who treats a patient outside the service, and whose liability therefore falls to be determined in accordance with the law of contract, assuming, of course, that the contract is in terms which impose upon him neither more nor less than the tortious duty."

${ }^{1}$ Thake v Maurice [1986] 1 All E.R. 497; Eyre V. Measday [1986] 1 All E.R 488; Edwards v Mallan [1908] 1 K.B. 1002; Pacific Associates Inc. v Baxter [1989] 2 All E.R. 159.

${ }^{2}$ Hussein Amer, Abdulraheem Amer, Supra n 4. p 64. Izzedine Aldnasouri, Abdulhamid Alshawarbi, Supra n.5, p 515. 
In principle, the consequences of the obligations of a contract only apply to the contractors, but they may extend to those who are not contractors, such as in the case of requirements for the benefit of others. ${ }^{1}$ Although the third party is not a party of the contract, they may be relevant on the basis of liability of tort, not contractual liability. ${ }^{2}$ Therefore, a doctor might be sued by the heir of patient for the damage caused to them.

\subsection{Elements of contractual liability of the doctor}

In Kuwaiti law, as with other legal systems, civil liability is made up of two main parties: contractual liability and tortuous liability. The elements of contractual liability are a fault, damage and causation. These will now be examined.

\subsubsection{Contractual fault}

Neither Kuwaiti Law nor English Law contain a definition of the term "contractual fault." Contractual fault comes from the failure of a doctor to implement his duty in the contract, whether it is a duty requiring the achievement of a particular result or an obligation requiring the adoption of a particular standard of care. If

${ }^{1}$ Such as heir apparent and heir at law.

${ }^{2}$ Izzedine Aldnasouri, Abdulhamid Alshawarbi, Supra n.5, p 516. 
the doctor does not perform his obligation arising from the contract, he is considered as having deviated from the behaviour of a prudent obligor. ${ }^{1}$

The contractual fault may be intentional or unintentional. The liability of a doctor in contractual liability does not include the creation of a new obligation, but is the consequence of an existent obligation as a result of the contract. ${ }^{2}$

The contractual fault comes from the obligation which the parties of the contract agreed on. If the duty was obligatory by law, the breach of obligation is not contractual fault. ${ }^{3}$ A fault cannot be deemed to exist unless one of two components exists. The first is physical representation; when the doctor does not execute his duty in a satisfactory way. The second is intentional representation; when a doctor refuses or does not perform his duty while he is able to do. ${ }^{4}$

${ }^{1}$ Hussein Amer, Abdulraheem Amer, Supra n. 4. p 287.

${ }^{2}$ Izzedine Aldnasouri, Abdulhamid Alshawarbi, Supra n 5, p 501.

${ }^{3}$ Hussein Amer, Abdulraheem Amer, Supra n 4, p 289. Ibrahim Aldosoki, The Contract and Individual Intention, ( $1^{\text {st }}$ ed, Kuwait, 1995), p 304-305.

${ }^{4}$ Ibrahim Aldosoki,Ibid, p 304-305. Izzedine Aldnasouri, Abdulhamid Alshawarbi, Supra n 5, p 501. 
A doctor who commences a relationship with a patient undertakes a duty of care to that patient. While a doctor-patient relationship may often seem contractual in nature, it is not essential that the patient expressly enter to a specific of terms of contract in order to a duty of care to be imposed on the doctor. Rather, the duty of care is required by law once the doctor undertakes to diagnose, treat, advice, consult about, or otherwise act with respect to the patient. ${ }^{1}$

The question which arises here is that what is the standard of care required to satisfy this duty? In the absence of an express term, a term will be implied into a contract to perform that a service will be provided with reasonable care and skill. ${ }^{2}$ The standard of care required to meet this duty is the same in the tort of negligence. ${ }^{3}$ The doctor does not give guarantee that the operation done to patient will be succeed. He just only gives a guarantee that he will perform the operation with reasonable care. If he does so, he will carry out the operation personally and pay such following

1 A. John Popp, A guide to the Primary Care of Neurological Disorders, (Thieme, New York, 1998), p 28.

${ }^{2}$ Eyre v. Measday [1986] 1 All E.R. 488; Thake v Maurice [1986] 1 All E.R. 497.

${ }^{3}$ Sidaway v Bethlem Royal Hospital Governors [1985]1 All E.R. 643, 665. 
visits as are required for the supervision of the patient until the cure of the patient. ${ }^{1}$

As a general rule the doctor cannot delegate his obligations and powers because he must act personally. Therefore, the doctor cannot delegate performance of operation to another doctor as contractual duties of care cannot be delegated. This will establish a breach of contract. The doctor will be answerable for a failure to exercise reasonable care performed by delegated person $^{2}$ even if that reasonable care has been exercised in selecting a proper person. ${ }^{3}$ A doctor employed in NHS has a duty to provide personal treatment to his patients. ${ }^{4}$

In most cases, the doctor's duties imposed by the contract are the same duties imposed by tort. Therefore, the existence of a

${ }^{1}$ Michael v Molesworth (1950) 2 B.M.J. 171.

${ }^{2}$ Izzedine Aldnasouri, Abdulhamid Alshawarbi, Supra n. 5, p 529.

${ }^{3}$ Michael A. Jones, Medical Negligence, $\left(2^{\text {nd }}\right.$ ed, Sweet \& Maxwell, London, 1996), p.22.

${ }^{4}$ By virtue of the contract of employment in the case of hospital doctors, and under the contract with the Family Health Services Authority (FHSA) (Formerly the Family Practitioner Committee) in the case of general practitioners. 
contract of private medical treatment does not affect the duties imposed by the doctor in practical terms. ${ }^{1}$

In absence of an express term, the court will be hesitated to hold that a doctor gave a contractual warranty achieving a specific outcome as medicine is an inaccurate science and it is improbable that a liable doctor would aim to give such a warranty. This approach was asserted in Eyre $v$ Measday, ${ }^{2}$ the plaintiff had a sterilisation operation executed by the defendant (doctor). The operation was performed by laparoscopic sterilisation which was clarified by the doctor that it was irreversible. However, the doctor did not tell the plaintiff that there was a less than one per cent risk of pregnancy happening following such a process. The operation was believed by both plaintiff and her husband that it would make the plaintiff totally sterile and there was no chance of a future pregnancy. Later, the plaintiff sued the doctor as became pregnant and he was in breach of a contractual term that she would be rendered to irreversibly sterile and inherent warranty to that effect which persuaded her to agree to the contact. The court held it was a contact to perform a specific operation, not a contact to make the

${ }^{1}$ Michael A. Jones, Supra n.25, p 22.

2 [1986] 1 All E.R 488. 
plaintiff sterile. Moreover, there was neither an express nor an implied warranty that the process would be decisive success. Although she could logically be finished from the doctor's assert on the irreversible nature of the operation that she would be sterile, it was not logical for her to have concluded that the doctor had given her a warranty that she would be completely sterile. This approached was emphasised in Thake $v$ Maurice. ${ }^{1}$ The plaintiff sued the doctor that had contracted to perform a operation that make the male plaintiff irreversibly sterile following a vasectomy operation. A graphic manifestation of nature of the process and its effect were explained to plaintiff by the doctor but he did not inform the plaintiff that he might become impregnated again. Both Neill and Nourse L.JJ. concluded that the doctor had not guaranteed the result, relying on the observation that medicine is an inaccurate science and outcomes are to some extent unexpected. ${ }^{2}$ Nourse added that the doctor cannot be considered giving a guarantee for result of operation unless he clearly mentions in terms. ${ }^{3}$

${ }^{1}$ [1986] 1 All E.R. 497.

${ }^{2}$ Ibid at p. 510, per Neill, it is not expected that the doctor will give a guarantee of 100 per cent success.

${ }^{3}$ Ibid, at p. 512. 
However, the court can infer from the doctor's words that there was an express or implied warranty given by a doctor to a patient. In the Canadian case of La fleur $v$ Cornelis ${ }^{1}$ plaintiff has a contract with cosmetic surgeon to make his nose's size smaller. The surgeon had shown the plaintiff the changes that would be performed. The operation had failed and the plaintiff had become distorted. Barry J concluded that the surgeon is strictly answerable for breach of contract virtue to that the surgeon has said to the plaintiff that there would be "no problem" and "you will be very happy." These words were considered to establish an express warranty of success.

Therefore, while it may be likely to constitute that a doctor has guaranteed a specific outcome, ${ }^{2}$ this is expected to be a scarce happening. ${ }^{3}$ In contrast, an announcement by the doctor that he could not guarantee the result, would appear to more possible event in exercise. ${ }^{4}$ In fact, some contractual terms have nothing to do with

${ }^{1}$ (1979) 28 N.B.R. (2d) 569 (N.B.S.C.).

${ }^{2}$ Thake v Maurice [1986] 1 All E.R. 497.

${ }^{3}$ The court may look to find express warranty of a successful result in particular case such as sterilisation operation and cosmetic surgery. For example in $L a$ Fleur v Cornelis (1979) 28 N.B.R. (2d) 569, 577.

${ }^{4}$ See Unfair Contract Terms Act 1977, s. 2(1,2,3). 
exercise of reasonable care and skill. ${ }^{1}$ So, if the doctor enters to contract requiring him to carry out particular act, such as employ a specific process, ${ }^{2}$ then he is answerable for failure to execute it regardless of whether he used reasonable care. ${ }^{3}$

Kuwaiti Law does not devote a separate section to the treatment of contractual liability, but the provisions of 227-237 and 290-293 of Kuwait Civil Law show the general elements of contractual liability. Provision 227 of Kuwait Civil Law stipulates that anyone suffering damage due to the 'fault' of a contractual party is entitled to compensation. The judgment of Kuwaiti courts uses the term of 'fault' to describe a non-performance of a contractual obligation. ${ }^{4}$

Therefore, any non-performance is a breach of contract when performance of duty under the contract is due. It is breach of

${ }^{1}$ Eyre v. Measday [1986] 1 All E.R. 488; Thake v Maurice [1986] 1 All E.R. 497.

${ }^{2}$ Edwards v Mallan [1908] 1 K.B.1002, 1005, C.A.

${ }^{3}$ Michael A. Jones, Supra n. 25, p 25.

${ }^{4}$ Adnan Amkhan, The Concept of Fault in the Arab Law of Contract, Arab Law Quarterly. Vol 9. No. 2 (1994). p 179. 
contract to fail without justification to fulfil all or any part of what is obliged in a contract. ${ }^{1}$

\subsubsection{Damage}

Damage is a major element giving rise to contractual liability in Kuwaiti law. If there is no damage, there is no contractual liability. ${ }^{2}$ However, in English law the action of damages can succeed even if the patient has not suffered any loss. ${ }^{3}$ In the event of damage, the doctor who did not perform his obligation would be liable to compensate the other patient who had lost. ${ }^{4}$ Nonperformance of the contract does not entail compensation unless it causes damage. ${ }^{5}$ The compensation includes what the injured party lost and mental distress. ${ }^{6}$

${ }^{1}$ G. H. Treitel, Remedies for Breach of Contract, A Comparative Account, (Clarendon Press, Oxford, 1988), p 8-9.

${ }^{2}$ Article 303 of Civil Kuwaiti Law.

${ }^{3}$ For more detail see G. H. Treitel, Supra n.40, p. 926.

${ }^{4}$ Izzedine Aldnasouri, Abdulhamid Alshawarbi, Supra n.5, p 571. Hussein Amer, Abdulraheem Amer, Supra n.4, p 332.

${ }^{5}$ Lazenby Garages Ltd v Wright [1976] 1 W.L.R. 459, CA.

${ }^{6}$ Geoffrey Samuel, Contract Law, Cases and Materials, $\left(1^{\text {st }}\right.$ ed, Sweet \& Maxwell, London, 2007), p 541-542. Hussein Amer, Abdulraheem Amer, Civil Liability, Contractual and Negligent Liability, $\left(2^{\text {nd }}\right.$ ed, Dar Almaaref, Egypt, 1979). p 332. 
The damage which is eligible for compensation in contractual liability is only that which is the expected damage. ${ }^{1}$ Compensation is limited to expected damage ${ }^{2}$ except in the case of fraud and wilful fault. ${ }^{3}$ Contractual liability is characterized as liability which rests on the contract. The parties specify their obligations when they make the contract ${ }^{4}$ and they can expect the amount of liability for breach of their obligations. ${ }^{5}$ The expected damage, required by contractual liability, requires a reasonable degree of certainty. The compensation for damage includes future harm. ${ }^{6}$

${ }^{1}$ Koufos $v$ Czarnikow (The Heron II) [1969] 1 AC 350 more exactly you recover for "reasonably contemplated as a not unlikely consequence of breach".

${ }^{2}$ Geoffrey Samuel, Supra n.45, p 531. Izzedine Aldnasouri, Abdulhamid Alshawarbi, Supra n. 5, p 572. Ibrahim Abdullah, The Civil Liability of Consultative Experts,( thesis, Cairo University, Cairo, 2003), p 234.

3 Article 300 of Kuwaiti Civil Law. Izzedine Aldnasouri, Abdulhamid Alshawarbi, Supra n.5, p 572.

${ }^{4}$ Hadley $v$ Raxendale (1854) 156 E.R. 145, Exch

${ }^{5}$ Ibrahim Aldosoki,Supra n.18, p 306. Hussein Amer, Abdulraheem Amer, Supra n. 4. p 333. Izzedine Aldnasouri, Abdulhamid Alshawarbi, Supra n. 5, p 572.

${ }^{6}$ Geoffrey Samuel, Supra n. 45, p 536. Izzedine Aldnasouri, Abdulhamid Alshawarbi, Supra n. 5, p 572. 
Therefore, the doctor is liable under contractual liability for expected damage, whether it is actual or future harm, when he enters into contract for treatment or operation. The damage may be pecuniary or mental distress. ${ }^{1}$ Pecuniary damage is that which causes damage to a patient in his body, money or loss of opportunity. ${ }^{2}$ The pecuniary damage is required to be absolute and not already compensated. ${ }^{3}$ The damage must be absolute to give rise to contractual liability. The damage must not be supposed or probable. ${ }^{4}$ Probable damage is that which has not occurred yet and is not certain to occur. ${ }^{5}$ It must be decided whether it constitutes actual or future harm.

The compensation must contain all damage, whether actual or future harm. Therefore, although the doctor is liable for realised damage whether actual or future, he is not liable for probable

${ }^{1}$ Watts $v$ Morrow [1991] 1 W.L.R. 1421, CA.

${ }^{2}$ Allied Maples Group Ltd v Simmons \& Simmons [1995] 1 W.L.R. 1602, CA. Hussein Amer, Abdulraheem Amer, Supra n.4, p 333.

${ }^{3}$ Hussein Amer, Abdulraheem Amer, Supra, n.4. p 333-337.

${ }^{4}$ Ibid. Izzedine Aldnasouri, Abdulhamid Alshawarbi, Supra n.5, p 572-573.

${ }^{5}$ Ibid. 
damage which may occur or not. ${ }^{1}$ The doctor may be obliged to compensate the patient for the mental distress caused by his fault. ${ }^{2}$ The mental distress is that damage which affects a person's noneconomic interests. ${ }^{3}$ Thus, the doctor may be obliged to compensate a patient for any damage affecting his reputation. ${ }^{4}$ The aim of compensation for such damage is not to remove the consequences of the damage, but to reduce the acuteness of its consequences. ${ }^{5}$

Compensation for damage requires that it has not already been compensated. There is no doubt that damage cannot be compensated more than once. If the doctor has compensated for the damage caused by him to the patient, the doctor should not compensate for the same damage again, unless some element of this damage has not yet been compensated for. ${ }^{6}$

${ }^{1}$ Ibid. Ibrahim Aldosoki, Civil Liability, Dar of Books for publishing, (Kuwait, 1995), p 86-87.

${ }^{2}$ Ibrahim Abdullah, Supra n. 47, p229.

${ }^{3}$ Tulba Wehba, Clause of Obligation between Alshariaa and Law, (Al Arab Thought Dar), p 65.

${ }^{4}$ Mahmud v BCCI [1998] A.C. 20, HL.

${ }^{5}$ Ibrahim Abdullah, Supra n.47, p229.

${ }^{6}$ Izzedine Aldnasouri, Abdulhamid Alshawarbi, Supra n. 5, p 572-575. Hussein Amer, Abdulraheem Amer, Supra n. 4. p 337-338. 
The damage in contractual liability is also required to be personal. Therefore, the plaintiff must prove that the damage occurred to him personally. ${ }^{1}$ The damage in contractual liability is also required to be related to a valid right. Therefore, the damages to be sought from the doctor for compensation must be related to a valid right which is protected by law.

It can be not from above that damage to give arise to contractual liability is required only by Kuwaiti Law not by English Law. So, in English Law the action of compensation can succeed even if the plaintiff has not suffered loss.

\subsection{3 causation}

It is not sufficient to give rise to contractual liability that the doctor does not perform his duty in the contract. A causal relationship must exist between the damage and non-performance. ${ }^{2}$ If a causal relationship is absent, contractual liability cannot be

${ }^{1}$ Vacwell Engineering Co Ltd v BDH Chemicals Ltd (1971). Hussein Amer, Abdulraheem Amer, Supra n.4. p 340.

${ }^{2}$ Soliman Marqas, Theory of the Contract and Individual Intention, $\left(4^{\text {th }} \mathrm{ed}\right.$, Dar of Jurisprudent Books, Egypt, 1987), p 559. Izzedine Aldnasouri, Abdulhamid Alshawarbi, Supra n.5, p 599. Hussein Amer, Abdulraheem Amer, Supra, n 4. p 352. Ibrahim Aldosoogi, Supra n. 18, p 308. 
existed. ${ }^{1}$ Therefore, the damage must show as a result of the fault. ${ }^{2}$ Consequently, causation is the third element required for contractual liability. ${ }^{3}$

Thus, to give rise to the contractual liability of the doctor, the damage caused to another party must be his fault. If the doctor's conduct contributes in any way at all to the plaintiff's loss, he is liable for compensation. ${ }^{4}$ Any breach of contract by the doctor which causes no loss does not raise questions of causation. ${ }^{5}$ If the damage which injures the patient is attributed to numerous causes, the causes that produced this damage must be identified. The damage must be a result of the doctor's fault to give rise to the contractual liability of the doctor. ${ }^{6}$ However, the doctor may be

${ }^{1}$ G. H. Treitel, Supra n. 40, p 170. Ibrahim Aldosoki, Supra n.18, p 308. In English Law the causation is not necessary, if the damage was absent, to give arise contractual liability. See Ewan Mckendrick, Contract law, $\left(8^{\text {th }}\right.$ ed, Palgrave Macmillan, England, 2009), p. 341. See also G. H. Treitel, Supra n. 40, p. 926.

${ }^{2}$ British Columbia Saw-Mill Co. Ltd v Nettleship (1868), L.R. 3 C.P. 499, 510.

${ }^{3}$ Ibrahim Aldosoki, Supra n. 18., p 308. Hussein Amer, Abdulraheem Amer, supra n.4. p 352.

${ }^{4}$ G. H. Treitel, Supra n. 40, p 170.

${ }^{5}$ Ibid, p 170-171. However, contractual liability in English law does not required the causation to give arise which is only required in Kuwaiti law.

${ }^{6}$ Monach Steamship Co v. Karlshamns Oljefabriker [1949] A.C. 196, 226. 
liable although his failure to perform the contract is not the sole cause of the loss. ${ }^{1}$ It has been put in an English case that 'if a breach of contract is one of two cases, both co-operating and both of equal efficacy ... it is sufficient to carry a judgment for damages. $^{2}$

In English and Kuwaiti Law the doctor whose default establishes one of a number of causes of the loss is fully liable or is not liable at all. It is not generally considered possible to reduce his liability in proportion to the degree of damage which his fault contributed to the loss. The only situation which can reduce the liability of the doctor is when the loss is partly caused by the act of the plaintiff himself. ${ }^{3}$

\section{Burden of proof}

In practice, the causal relationship between the fault and the damage is supposed. The plaintiff is not adhered to prove it, but the defendant is obliged to prove that the causal relationship does not

${ }^{1}$ Ibrahim Abdullah, Supra n.47, p246.

${ }^{2}$ Heskell v. Continental Express Ltd. [1950] 1 All E.R. 1033, 1048.

${ }^{3}$ G. H. Treitel, Supra n. 40, p 171-172. Izzedine Aldnasouri, Abdulhamid Alshawarbi, Supra n.5, p 604. Hussein Amer, Abdulraheem Amer, Supra n.4. p 354. Soliman Marqas,Supra n. 64, p 599. 
exist. Therefore, the burden of proof rests on the defendant, who cannot avoid liability unless he proves that the non-performance or delay in performance is due to a foreign cause beyond his control. ${ }^{1}$

Therefore, if the plaintiff proves that the doctor has not fulfilled his obligation and that damage has been incurred, there is a simple indication in his favour that this damage is attributable to the doctor's fault, represented in non-performance or delay in performance of the contract. Such an indication is not absolute and the doctor can rebut it by proving foreign cause, which is the act of the plaintiff or another party. ${ }^{2}$ However, in English law the plaintiff is just required to prove doctor's fault (non-performance) to get compensation.

\section{Tort of negligence}

Medical negligence is sometimes called "malpractice" though these terms are not firmly synonymous, as professional misconduct also may be described as malpractice. Most cases of medical negligence are derived from civil law. Every one, whether a doctor or not, has a duty to take care not to harm his neighbour. Negligence, whether medical or otherwise, is civil wrong know as a

${ }^{1}$ Article 293 of Kuwaiti Civil Law. Adnan Amkhan, Supra n. 39, p175-176.

${ }^{2}$ Ali Negeida, General Theory of Obligation, $\left(1^{\text {st }}\right.$ ed, 1994), p 501. 
tort, where a doctor fail to take competent care, so that damage result.

The most majority of claims for medical malpractice are taken in the tort of negligence, where the matter will generally be whether the doctor was in breach of a duty of care and whether the breach caused damage to patient. ${ }^{1}$ Usually, it easy to determine a duty of care imposed by the doctor to his patient, even if there was a contractual relationship. ${ }^{2}$

A legal action for negligence is the patient's claim for compensation for losses caused by the doctor. For a patient to succeed in a claim for doctor negligence, all the following elements must be proved. ${ }^{3}$

1. The doctor owed him a duty of care to patient.

2. The doctor was in breach of that duty.

3. The patient suffered damage caused by the breach of duty. These elements will be examined in more details.

${ }^{1}$ Michael A. Jones, Supra n 25., p 29.

${ }^{2}$ Edwards v Mallan [1908] 1 K.B. 1002.

${ }^{3}$ Lochgelly Iron Co. v M'Mullan [1934] A.C. 1,25,per Lord Wright. See also John Cooke, Law of tort, $\left(8^{\text {th }}\right.$ ed, Pearson Education Limited, Harlow, 2007), p. 31 . 


\subsection{Duty of care}

The duty of care defines as a matter of policy whether the type of loss caused to the patient in the specific way in which it happened can ever be actionable, while breach of duty treats the standard of care imposed on the doctor in the circumstances so as to satisfy the duty of care, whether the doctor was careless or neglect. ${ }^{1}$

A doctor must have a reasonable degree ${ }^{2}$ of proficiency and apply that proficiency with a reasonable level of prudence. Therefore, an exceptionally clever doctor may be careless if he fails to apply his intelligence. On the contrary, an incompetent or inexperience doctor may be careless even if he strains himself to the highest, if he has held himself out to the patient to be got of sufficient adequacy. This degree of adequacy is not constant level, but is changeable according to position of the doctor. It is difficult for a doctor to be realised for all present medical facts and be also able to apply all known diagnostic and curative method, but a

${ }^{1}$ Michael A. Jones, Supra n. 25, p 31.

${ }^{2}$ Xiju Zhao, The Duty of Medical Practitioners and CAM/TCM Practitioners to Inform Competent Adult Patients about Alternatives, (Springer, London, 2013) p. 186. 
doctor with a specific standing is required to have the awareness and competence equal with that status. ${ }^{1}$

In common terms, a person must carry out activities including a risk of injury to other with the care expected of a reasonable person in order to avoid being in breach of duty. In the classic formulation of Alderson B in Blyth v Birmingham Waterworks Co:

"Negligence is the omission to do something which a reasonable man, guided upon those considerations which ordinarily regulate the conduct of human affairs, would do, or doing something which a prudent and reasonable man would not do.",2

The concept of reasonable person embodies, in reality, a mandatory factor reflecting the court's sense of how a person should act, though this concept at first view suggests the care of ordinary people. Lord MacMillan in Glasgow Corporation v Muir stated that:

"Some persons are by nature unduly timorous and imagine every path beset with lions. Others, of more robust temperament,

${ }^{1}$ Bernard Knight, Legal aspect of medical practice, $\left(5^{\text {th }}\right.$ ed, Elsevier Science Limited, 1992), p 59-60.

${ }^{2}$ (1856) 11 Exch 781, 784. 
fail to foresee or nonchalantly disregard even the most obvious dangers. The reasonable man is presumed to be free both from over-apprehension and from over-confidence."1

The marker decision of Donoghue v Stevenson ${ }^{2}$ and the wellknown dictum of Lord Atkin ${ }^{3}$ were the common starting place for any argument of the duty of care in the tort of negligence. Its impact in the situation of medical negligence is a bit partial, however, since the duty of care imposed on a doctor to his patient before the dates of Donoghue $v$ Stevenson, and the relationship between doctor and patient obviously satisfies any assessment based upon expectation of damage, proximity of the relationship between claimant and defendant, or a condition that it be mere and reasonable to require a duty of care. ${ }^{4}$

It is apparent that the nature and variety of the activity will determine what is required to a person to perform a duty of care as Lord MacMillan said that "Those who engage in operations

${ }^{1}$ [1943] AC 448 (HL) 457.

${ }^{2}$ [1932] A.C. 562.

3 "'You must take reasonable care to avoid acts or omissions which you can reasonably foresee would be likely to injure your neighbour." Ibid at p. 580

${ }^{4}$ Peabody Donation Fund $v$ Sir Lindsay Parkinson \& Co Ltd [1984] 3 All E.R. 529; Pacific Associates Inc. v Baxter [1989] 2 All E.R. 159, 189. 
inherently dangerous must take precautions which are not required of persons engaged in the ordinary routine of daily life",

Historically, the doctor has been held liable for a failure to exercise reasonable care in treating his patient, independently of any contractual terms with the patient. The doctor exercised a "common calling" which established a duty to exercise competent care and skill. ${ }^{2}$ At present the duty establishes from the tort of negligence, however, it does not rely on the doctor's position, qualifications or knowledge. Rather it is owed by law when the doctor performs the duty of providing opinion, diagnosis or treatment. As Lord Hewart C.J. ${ }^{3}$ said:

"If a person holds himself out as possessing special skill and knowledge and he is consulted, as possessing such skill and knowledge, by or on behalf of a patient, he owes a duty to the patient to use due caution in undertaking the treatment. If he accepts the responsibility and undertakes the treatment and the patient submits to his direction and treatment accordingly, he owes a duty to the patient to use diligence, care, knowledge, skill and

${ }^{1}$ Glasgow Corporation v Muir [1943] AC 448 (HL) 456.

${ }^{2}$ Holdsworth, History of English Law, Vol. III, pp. 385-386.

${ }^{3}$ R. v Bateman (1925) 94 L.J.K.B. 791 at p. 794 
caution in administering the treatment. No contractual relation is necessary, nor is it necessary that the service be rendered for reward."

There is no legal duty upon a doctor to give aid to a stranger who been involved in an accident, however, if he does so he will be obliged to exercise duty of care to the patient. A reasonable care takes into account the circumstances in which a doctor has to act. If the fault is one which a reasonably proper doctor would have done in circumstances the doctor is not liable for negligence. On the contrary, if a reasonably proper doctor could not have made that fault the doctor will be accountable, notwithstanding the reality that it happened in the course of an emergency. ${ }^{1}$

Furthermore, the one who does not own relevant qualification, knowledge or skill comes under the same duty of care, since by undertaking the treatment he in fact represents that he does possess these features. ${ }^{2}$ This approach has been taken in medical injury cases regarding errors caused by inexperienced doctors. In Wilsher

${ }^{1}$ Cattley v St John's Ambulance Brigade (1988, Q.B.D., unreported). Citing Michael A. Jones, supra n. 25, p 138.

${ }^{2}$ R. v Bateman (1925) 94 L.J.K.B. 791, 794. 
$v$ Essex Area Health Authority, ${ }^{1}$ a junior doctor in specialist baby unit took mistakenly blood-oxygen measurements for a premature baby which caused to the baby being over-saturated with oxygen, which allegedly led his following blindness. In judgment Glidewell LJ explained:

"In my view, the law requires the trainee or learner to be judged by the same standard as his more experienced colleagues. If it did not, inexperience would frequently be urged as a defence to an action for professional negligence.", And he added "If this test appears unduly harsh in relation to the inexperienced, I should add that, in my view, the inexperienced doctor called upon to exercise a specialist skill will, as part of that skill, seek the advice and help of his superiors when he does or may need it. If he does seek such help, he will often have satisfied the test.",

Accordance with "mere omission" rule a person who chooses to perform must act so closely so as to keep away from causing injury on others, but, as a general rule, the tort of negligence does not require a person to take positive acts to give a benefit on others.

${ }^{1}$ [1987] Q.B. 730.

${ }^{2}$ Netteleship v Weston [1971] 2 QB 691 (CA).

${ }^{3}$ Wilsher v Essex Area Health Authority [1987] Q.B 730 (CA) 744. 
Person has no legal duty to give help to someone in danger, even if aid would include little effort or nothing the aider. ${ }^{1}$ Therefore, if a relationship between a doctor and patient has existed, the doctor may be accountable for failing to attend or treat the patient, just as much as neglect treatment. The duty of care will apply as soon as a doctor accepted the patient for treatment. ${ }^{2}$

What is the standard of care supposed in emergency circumstances? An emergency might really be determined as abrupt disjunction between an unexpected incident and the resources obtainable to deal with it. The courts will take account of the uncommon circumstances when it defines the standard of care of an individual doctor who acts in emergency events. as Mudtill LJ stated that:

"An emergency may overburden the available resources, and, if an individual is forced by circumstances to do too many things at once, the fact that he does one of them incorrectly should not lightly be taken as negligence.",

${ }^{1}$ Michael A. Jones, Supra n. 25, p 35.

${ }^{2}$ Jones v Manchester Corporation [1952] 2 All E.R. 125, 131.

${ }^{3}$ Wilsher v Essex Area Health Authority [1987] QB 730 (CA) 749. 
The reason was that it is expected that a doctor may have been required to take quick decisions on the ground of insufficient awareness. Likewise, if the existence of the emergency accepted interference by someone without the professional skills perfectly needed, the latter will only be held to the standard of someone with their factual skills. ${ }^{1}$

With regard to an area of medicine, a vital part of this will relate to the awareness of the dangers attaching to a provided interference. Doctors will be required to keep reasonably up to date with medical development by looking at a new researches and technique used recently. ${ }^{2}$ However, the court will be reluctant to judge the doctor's behaviour by indication to those risks knowable at the time. In Roe $v$ Minister of Health, ${ }^{3}$ two patients were paralysed caused by contamination occurred in the storage ampoules which previously unknown danger. In decision against the hospital's liability, Denning LJ stated that:

${ }^{1}$ Marc Stauch, The Law of Medical Negligence in England and Germany, A Comparative Analysis, (Hart Publishing, USA, 2008), p.35.

${ }^{2}$ Crawford v Charing Cross Hospital (CA), The Times, 8 December 1953.

${ }^{3}$ Roe $v$ Minister of Health [1954] 2 QB 66 (CA) 83. 
"It is so easy to be wise after the event and to condemn as negligence that which was only a misadventure. We ought always to be on our guard against it, especially in cases against hospitals and doctors. Medical science has conferred great benefits on mankind, but these benefits are attended by considerable risks. Every surgical operation is attended by risks. We cannot take the benefits without taking the risks. Every advance in technique is also attended by risks. Doctors, like the rest of us, have to learn by experience; and experience often teaches in a hard way.",

A main aspect of reasonable skill and care approach is it objectivity. This approach was adopted in Glasgow Corporation $v$ Muir. As Lord MacMillan said that "eliminates the personal equation and is independent of the idiosyncrasies of the particular person whose conduct is in question.",2

Kuwaiti Law does not distinguish between gross negligence and ordinary negligence and it simply stipulates that if the debtor is required to keep something or manage it or is required to take

${ }^{1}$ Ibid.

${ }^{2}$ Glasgow Corporation v Muir [1943] AC 448 (HL) 457. 
prudent care in implementing his obligation, he will be discharged if he acts as an ordinary man. ${ }^{1}$

Therefore, there is no distinction between gross negligence and ordinary negligence in Kuwaiti law. The professional person is liable for any fault committed by him whether it is gross or not. ${ }^{2}$ There is no legal base distinguishing between ordinary negligence and gross negligence and there is no specific provision exempting a person from professional liability in cases of ordinary negligence. ${ }^{3}$

The Kuwaiti court ${ }^{4}$ stated that the doctor must follow the proper diagnostic procedure and take the common medical examination $^{5}$. It was also held ${ }^{6}$ that the doctor's fault must be

${ }^{1}$ Provision 290 of Kuwaiti Civil Law.

${ }^{2}$ Mirfat Abdalaal, Consultant Contract in Information system, (Thesis, Hilwan University, 1997), p. 399. Salama Ahmad, Notices in Obligation Theory, $\left(1^{\text {st }}\right.$ ed, Ain Shams Library), p. 266. The Egypt Supreme Court stated that the doctor is required to exercise prudent care which is consistent with medical principle, so he will be liable for professional negligence and ordinary negligence. Egypt Supreme Court, No 461 of year of 36, 21/12/1971, p. 1062.

3 Abdalrahman Hamdi, Body Safe Guarding, Research in the Problems of Medical Liability, 1987, p. 21.

${ }^{4}$ Kuwaiti Supreme Court, Case No 66, 69/2003 dated 27/10/2003.

${ }^{5}$ Kuwaiti Supreme Court, Case No.519/2010 dated 20/04/2011.

${ }^{6}$ Kuwaiti Supreme Court, Case No 99/2003 dated 22/12/2003. 
obviously proved that he performed unprofessionally, whether he was unknown or negligent, in contrary to basic and scientific principle of medical treatment.

\subsection{The doctor was in Breach of a Duty of Care.}

Just as a patient needs to show that the doctor owed a duty of care, it is important to demonstrate that the doctor was in breach of that duty. ${ }^{1}$ The patient must prove that the doctor was negligent and this may be the most difficult task. ${ }^{2}$ The plaintiff may not know precisely what had occurred and ascertaining the facts could be both difficult and costly. In practice, the failure and success of most negligence actions rest on the patient's ability to demonstrate negligence. ${ }^{3}$ In liability of negligence, the damage is an essential element of the cause of action of negligence where it is not an essential element of the cause of action for breach of contract.

There are several aspects that the doctor can be shown as a breach of duty of care. These situations will be examined now.

${ }^{1}$ John Cooke, Supra n 78. , p. 128.

2 Emily Jackson, Medical Law Text, Cases and Materials, (3ed, Oxford University Press, London, 2013) p. 112.

${ }^{3}$ Ibid. 


\subsubsection{Failure to attend or treat}

If attendance of doctor was essential in his patient's health, he may be guilty of negligence for failing to attend or delaying in attending. However, this will take account the accurate circumstances of the case related to the patient and other patients at the same time. Middleton J. in Smith v Rae found that the doctor was not negligent. The patient was pregnant and she was about to deliver. The doctor had undertaken to attend the patient at her birth expected by an experienced midwife that would not be until 11 p.m. He was called at 7.30 p.m. but engaged with other patient and he could be there until 8.30 p.m. The child passed away during birth which happened before 8.30 p.m. Similarly, in Kavanagh $v$ Abrahamson, ${ }^{2}$ the court held that the doctor was not negligent for attending to his patient.

${ }^{1}$ (1919) 51 D.L.R. 323.

2 (1964) 108 S.J. 320. The patient changed his address without telling his doctor. The doctor moved to old address but he got no response. The patient died as a result of having bronchitis. 
In Barnett v Chelsea and Kensington Hospital Management Committee $^{1}$ the doctor was held a negligent for failing to attend to patient who were came to hospital after drinking some poison tea. The doctor asked them by her nurse to go home and see their own doctor. They went home and after five hours later one of the patients died. The doctor was breach in his duty to attend because he did not come to see and examine the patients.

The failure to treat and examine the patient may lead the doctor to be negligent. In Corder v Banks ${ }^{2}$ the patient was allowed to go home after an operation on his eye-lids. The fault of doctor was in failure to make any arrangements for the patient to speak to him in the case of bleeding appearing during the 24 hours after operation. However, his duty of attending does not widen to supervising routine dealings executed by treatment staff. ${ }^{3}$

Therefore, the doctor may be negligent if he failed to attend and treat to his patient without reasonable reason.

${ }^{1}$ (1968) 1 All E.R. 1068.

${ }^{2}$ The times, April 9, 1960.

${ }^{3}$ Morris v Winsbury-White [1937] 4 All E.R. 494. 


\subsubsection{Errors in Diagnosis}

There are many cases such as diagnostic errors which the doctor can be in breach of his duty. ${ }^{1}$ The doctor may fail to consider the patient's medical history. ${ }^{2}$ In any treatment, common sense says that it is naturally risky to try to make a diagnosis without first considering the patient's medical history, and then asking him related questions. ${ }^{3}$ The patient may be suffering from allergy to a specific drug. ${ }^{4}$ So, the doctor must pay attention to the patient's description of the illness, while being careful not to fasten too much significance to the patient's self diagnosis. The doctor must check the patient and come to his own diagnosis.

The patient's medical record may contain not only the references and symptoms of the sickness for which the patient is in quest of treatment, but also information of any prior treatment

${ }^{1} J D v$ East Berkshine Community Health NHS Trust [2005] UKHL 23.

${ }^{2}$ Rachael Mulheron, 'Trumping Bolam: A Critical Legal Analysis of Bolitho's "Gloss"”' (2010) 69 Cambridge Law Journal 609-38.

${ }^{3}$ Cassidy v Ministry of Health [1951] 2 KB 343; Chin Keow v Government of Malaysia [1967] 1 W.L.R 813.

${ }^{4}$ Hollingsworth $v$ Dartford and Gravesham Health Authority (1993) 4 A.V.M.A. Medical ט Legal Journal (No. 3) p. 13. 
either for the same circumstances or a preceding wound or illness. ${ }^{1}$ In Coles v Reading and District Hospital Management Committee ${ }^{2}$ the patient has injured in his finger and went to cottage hospital and had the first-aid treatment by nurse but he was not given an antitetanus injection. He was asked to go to battle hospital for additional treatment but he took days to go to the hospital. Afterwards, he went to his own doctor who did not take any reaction to what did he take at the hospital and simply treated the wound. Later the patient died of toxaemia due to tetanus infection as he had not been given an anti-tetanus injection. It was held that both the cottage hospital and the general doctor are liable. ${ }^{3}$

A wrong diagnosis, as any medical error, will not essentially be liable. However, it must always be remembered that the test is what reasonable doctor would have done by reference to the Bolam test. It will take into account to a great extent upon the hardness of making the diagnosis given the symptoms obtainable, the diagnostic mechanism available such as examinations or tools, and

${ }^{1}$ Jonathan Herring, Medical Law and Ethics, $\left(5^{\text {th }}\right.$ ed, Oxford University Press, London, 2014) p 109.

2 (1963) 107 S.J. 115.

${ }^{3}$ Ibld. 
the risks associated with the substitute diagnoses, and additional test may be suitable and the real steps imposed to make precise diagnosis, For example, the use of diagnostic assistance. ${ }^{1}$ A familiar part for wrong diagnosis relates to fractures. ${ }^{2}$ In Maynard $v$ West Midlands Regional Health Authority ${ }^{3}$ the patient claimed that two specialist doctors were careless in failing to diagnose tuberculosis, and subject her to a needless operation. They recognised that tuberculosis was most likely diagnosis, but there was a potential that the patient was suffering from Hodgkin's disease, which at the time could lead to be deadly unless the patient had early action. The doctors decided to perform a diagnostic operation to the patient which caused damage to the patient's left laryngeal recurrent nerve. The patient claimed that he was not needed to have operation as the tuberculosis was so clear. The House of Lords held that a accountable body of professional estimation approved of what the doctors had acted and therefore, they were not answerable, according to the Bolam test.

${ }^{1}$ Whiteford v Hunter [1950] WN 553.

${ }^{2}$ Fraser v Vancouver General Hospital [1951] 3 WWR 337; Hotson v East Berkshire HA [1987] AC 750.

${ }^{3}$ [1984] 1 W.L.R. 634. 
In some cases, the negligence can be arisen not that the diagnosis was wrong but the patient's condition was so serious that the doctor should either have referred the patient to a specialist who was competent to make the diagnosis or, at very least, carried out further test required for more precise diagnosis. For example, in Dale $v$ Munthali, ${ }^{1}$ the patient was diagnosed by the doctor as suffering from influenza, but in reality he had meningitis. It was held that the doctor was not negligent to diagnose meningitis, but the negligence comes from that the doctor should have realised that the patient was so really ill that was more than gastro-intestinal flu. Therefore, the doctor is advised that where he doubts that the condition is more serious, he must do further test.

In defining that the doctor has failed to meet the required standard of care, he would do well to keep an open mind about the cases of the patient's condition if it does react to treatment. A doctor who rejects to move from his first assessment from the patient's condition, notwithstanding the patient's obvious deterioration, is at the danger of being negligent. ${ }^{2}$

${ }^{1}$ (1976) 78 D.L.R. (3d) 588.

${ }^{2}$ Layden v Cope (1984) 28 C.C.L.T. 140 (Alta.Q.B.); Stacey v Chiddy [1993] 4 Med LR 345. 
The doctor is under a duty either to take advice from a competent consultant or to refer the patient to a consultant if he was unable to diagnose or treat the patient. In Poole $v$ Morgan ${ }^{1}$ although the ophthalmologist had often used a laser in his work, he was insufficiently qualified to exercise it in practice. The ophthalmologist gave the patient which must be given by a retina vitreous specialist. The ophthalmologist had to refer the patient to such a specialist as he has not had the standard of that specialty. Moreover, the doctor may be held a negligent if he doubted a cancer and he did not instantaneously refer the patient to a specialist or arrange for an urgent biopsy. ${ }^{2}$

In Kuwait, the court ${ }^{3}$ held that doctor was negligent for error diagnosis. The patient entered the hospital for treatment. The doctor diagnosed wrongly that the patient has abortion case and must do an operation for her. After the patient had the operation, the

${ }^{1}$ [1987] 3 W.W.R. 217

${ }^{2}$ Sutton v Population Services Family Planning Programme Ltd, The Times, November 7, 1881; Judge v Huntingdon Health authority [1995] 6 Med. L.R. 223.

${ }^{3}$ Kuwaiti Supreme Court, Case No. 66, 69/2003 dated 27/10/2003. See also Kuwaiti Supreme Court, Case No. 254/1998 dated 28/05/2001 Kuwaiti Supreme Court, Case No.86/ 2011 dated 03/04/2012. . 
doctor's diagnosis was wrong. The operation caused bleeding and explosion in the right fallopian tube. The patient claimed the doctor and his hospital to compensate her for this error. The court responded to her claim and held that the doctor was negligent as did not follow the proper diagnostic procedure and medical examination accepted.

\subsubsection{Failure of Advice and Communication}

Failures of communication between doctor and patient or between practitioners may give arise a negligence. ${ }^{1}$ The doctor has a duty to give sufficient advice to facilitate the patient to make a reasonable assessment about treatment and give valid consent. ${ }^{2}$ The patient has to prove that lack of information caused the loss to him. For example, the patient has to prove that if he was given further information he would not agree to do the operation. In Chester $v$ $A f s h r^{3}$ the patient has agreed to do operation to remove three spinal discs. The doctor did not inform her that there is a $1-2 \%$ of risk of damage to the nerve basis. The patient suffered nerve

1 Emily Jackson, Medical Law Text, Cases and Materials, (3ed, Oxford University Press, London, 2013) p. 177.

${ }^{2}$ Fallon v Wilson [2010] EWHC 2978 (QB).

${ }^{3}$ [2004] UKHL 41. 
damage and became disable as a result of operation. The patient claimed that the doctor performed the operation negligently and she would not agree to do the operation if she had been warned about the serious risks. The court found that the doctor was negligent for performing the operation but his negligence came from not warning the patient of the risk of disability.

Whether a doctor has performed carelessly is not evaluated by the common negligence standard of the reasonable person, but by the Bolam test. This gives that if a doctor meets standard of 'reasonable body of medical opinion"1 they are not negligent. The doctor would be negligent if the patient claimed that he had not been provided sufficient information about the risks. In Catterton $v$ Gerson, ${ }^{2}$ Bristow J said that:

In my judgment once the patient is informed in broad terms of the nature of the procedure which is intended, and gives her consent, that consent is real, and the cause of the action on which to base a claim for failure to go into risks and implications is negligence, not trespass. Demonstrate A failure to tell the patient how to avoid the probable risks involved in the treatment will be

${ }^{1}$ Bolam v Friern HMC (1957) per McNair J. ${ }^{2}$ [1981] Q.B. 432. 
carelessness. In Stamos v Davies $^{1}$ the doctor was doing a lung biopsy, a process which needed absolute co-operation by the patient, to remain still while it was performed. The patient's spleen was pierced by the doctor because the patient moved. The doctor was held liable as he had failed to be more communication with the patient which makes him more confidence about what was necessary for him in this circumstance.

\subsubsection{Errors in Treatment}

Doctors must have the degree of skill-including education and medical judgement that is owned by standard doctor of the same school of education who is exercising in the same area.

In operations, there are number of persons involved (surgeon, surgeon's assistances, nurses and anaesthetist) each with their own obligations and liabilities. ${ }^{2}$ In the event of operations performed by the NHS, the patient must prove only the error on the part of someone for whom the hospital authorities will be indirectly

${ }^{1}$ (1986) 21 D.L.R. (4 $\left.{ }^{\text {th }}\right)$ 507; Clarke v Adams (1950) 94 S.J. 599.

${ }^{2}$ Eugen H. Buhle, "Successful Strategies to Detect and Avoid Failure' in Walter Merkle, Risk Management in medicine (2016 edition, Springer, 2015) pp. 34-36. 
responsible. ${ }^{1}$ However, the patient is required to determine the particular person at fault in the case of operation under private treatment where he has dealt with a particular surgeon for whom the hospital is not indirectly liable.

Usually, a doctor will not liable for negligence of another in the team, whether it be the anaesthetist or a nurse, in implementing directions that have been given about the patient's treatment. ${ }^{2}$ On the contrary, the doctor may be liable if he recognises or should logically have recognized that another person in the team has made something which causes a risk to the patient but fails to take any actions to deal with the fault. ${ }^{3}$

It is usually evidence of negligence where a patient suffers from burns in an operating theatre. Therefore, an explosion occurred by a spark igniting a mixture of ether and oxygen can be indicative of negligence of anaesthetists. ${ }^{4}$

${ }^{1}$ Cassidy v Ministry of Health [1951] 2 K.B. 343.

${ }^{2}$ Wilsher v Essex Area Health authority [1986] 3 All E.R. 801, 812-813.

${ }^{3}$ Ibid.

${ }^{4}$ Crits v Sylvester (1956) 1 D.L.R. (2d) 502. 
The doctor may be liable for negligence for failing to prevent the patient from infection that he got it from hospital. ${ }^{1}$ It was held that the hospital authorities were negligent in placing the patient in a ward where there was a seriously equivocal case of infection and in failing to inform the patient. ${ }^{2}$

The doctor may be liable for patient for using injections in the wrong place, or the needle may break. In Collins v Hertfordshire Country Council $^{3}$ a patient passed away after taking injection of cocaine instead of procaine as a local anaesthetic, because of misunderstanding between the surgeon and the inexpert doctor who has been asked to prepare the anaesthetic. It is held that the surgeon is liable and must take responsibility for what he injects into patient.

The treatment given to the patient imposes a duty on the doctor to be observed, especially where the treatment may contain a high risk of a counter reaction. ${ }^{4}$ In Poole v Morgan ${ }^{5}$ it was held that

${ }^{1}$ Lindsey Country Council v Marshall [1937] A.C. 97.

${ }^{2}$ Heafield v Crane, The Times, July 31, 1937.

${ }^{3}$ [1947] 1 K.B. 598.

${ }^{4}$ Male v Hopmans (1967) 65 D.L.R. (2d) 105, 113-115 (Ont.C.A.).

${ }^{5}$ [1987] 3 W.W.R. 217. 
the doctor was negligent for delaying in examining the patient after he had received laser treatment on his eye. A delay of one month to examine was too long. ${ }^{1}$

In Kuwait, the court ${ }^{2}$ was held that doctor was negligent for error in treatment. The patient entered to the hospital to do operation to remove the left kidney. The doctor negligently cut the artery feeding the both kidneys which caused removing the right kidney as well. So the court stated that this error makes the doctor's liability for negligence establishes. ${ }^{3}$

\subsubsection{Contributory Negligence}

Where the doctor acts negligently and hurt a patient, the legal effect in the form of financial compensation may be decreased if the patient acts on his own consideration to worsen the harm or related its recovery. For example, a doctor may need the patient's co-operation to enable him to get clear vision to make a precise diagnosis or for the reason of managing the treatment. A doctor

${ }^{1}$ See also Coyne $v$ Wigan Health Authority [1991] 2 Med.L.R. 301, Q.B.D. where the doctor was held negligent in monitoring the patient who was in recovery ward following an operation under general anaesthetic and occurred to brain damage by hypoxia for a period of four to five minutes.

${ }^{2}$ Kuwaiti Supreme Court, Case No. 65/1998 dated 22/16/1998.

${ }^{3}$ Kuwaiti Supreme Court, Case No. 86/ 2011 dated 03/04/2012. 
may need reasonably precise information related to the patient's case, symptoms or medical history and the patient may incorrectly give him information or forget to tell him that he has allergy to penicillin. The patient may ignore doctor's instructions for his treatment which contributes to existence of damage. Section 4 of the Law Reform (Contributory Negligence) Act 1945 which says that, "Where any person suffers damage, partly as his own fault and partly as the fault of others, a claim in respect of that damage shall not be defeated by reason of the fault of person suffering the damage; but the damages recoverable in respect thereof shall be reduced to such an extent as the Court thinks just and equitable, having regard to the claimant's share in the responsibility for the damage". Similarly, Kuwaiti law ${ }^{1}$ stipulates that if the fault of the person (doctor) shared with the injurer's fault (patient) in causing the damage, he would not be adhered to compensate the injured but only to the extent that his fault caused the damage taking into account contributing injurer's fault in causing the damage. The burden of proof, in claiming that there was contributing negligence, is on the doctor to prove that it existed.

${ }^{1}$ Kuwaiti Civil Law, s 234. 


\subsection{The patient suffered damage caused by the breach of duty}

The third element in the plaintiff's case for negligence is causation. It is not sufficient to establish the doctor's liability the existence of a duty of care and its breach. Rather, the causation between the duty of care and breach of such duty must be proved. The claimant must demonstrate that their damage was caused by the doctor's breach of duty. ${ }^{1}$ The causation is divided into causation in fact and causation in law. Causation in fact deals with the question of whether as a matter of fact the damage. was caused by the breach of duty. ${ }^{2}$ The 'but for' test is the starting stage for assessing whether the doctor's breach of duty is a factual cause of the patient's damage. This central test is that the damage would not have happened but for the breach of duty. ${ }^{3}$

The damage may be refused even where the patient is able to prove a factual tie between the breach of duty and the damage. This would be on the ground that breach of duty requires the legal cause of the damage. ${ }^{4}$

${ }^{1}$ John Cooke, Supra n. 78, p.143.

${ }^{2}$ Ibid.

${ }^{3}$ Barnett $v$ Chelsea and Kensington Hospital Management Committee [1969] 1 QB 428.

${ }^{4}$ John Cooke, Supra n. 78, p. 160. 
In Kuwaiti law, it is not sufficient to give rise to negligent liability that the doctor does not perform his duty. A causal relationship must exist between the damage and non-performance. ${ }^{1}$ If a causal relationship is absent, negligent liability does not exist. ${ }^{2}$ Thus, the damage must occur as a result of fault. ${ }^{3}$

The Burden of Proof To establish the doctor's liability for negligence, the patient must prove elements of such liability, which are negligence, damage and causation. The court will evaluate the incidence of damage and the causation by examining the evidence given by the patient and questioning the doctor. ${ }^{4}$

The most difficult step which faces the plaintiff is how to verify that the doctor was negligent. ${ }^{5}$ For example, in Kay $v$ Ayrshire and Arran Health Board ${ }^{6}$ the plaintiff, who was a child, was unable to demonstrate that an overdose of penicillin could ever

${ }^{1}$ Kuwaiti Supreme Court, Case No. 86/ 2011 dated 03/04/2012. Soliman Marqas, Supra n. 64, p 559. Izzedine Aldnasouri, Abdulhamid Alshawarbi, Supra n.5, p 599. Hussein Amer, Abdulraheem Amer, Supra n.4 . p 352. Ibrahim Aldosoki, Supra n 18. , p 308.

2 Ibrahim Aldosoki, Supra n. 18, p 308.

${ }^{3}$ British Columbia Saw-Mill Co. Ltd v Nettleship (1868), L.R. 3 C.P. 499, 510.

${ }^{4}$ Ibrahim Aldosoki, Supra n. 57, p. 131.

${ }^{5}$ John Cooke, Supra n 78. , p.137.

${ }^{6}$ [1987] 2 All E.R. 417. 
cause deafness. He was suffering from meningitis and was carelessly taken 30 times the right dose of penicillin. Later, the overdose caused deafness to the patient. The overwhelming weight of medical opinion was to the effect that penicillin did not lead to deafness. The burden of proof rests on the plaintiff in a negligence case to verify that the doctor breached a duty of care imposed on him. ${ }^{1}$ In Kuwaiti case, it was held ${ }^{2}$ that the doctor was negligent for patient's treatment. The patient went to hospital as she felt pain in her ankle. The doctor gave her local injection with cortisone. She frequently went to the hospital with no avail and the pain was strongly increased. She went to another hospital that found out that she had incorrectly an overdose of treatment caused disability of walking.

In some cases the negligence of a doctor is clearly obvious and does not need a vast deal of effort to verify it. Conversely, the plaintiff may not be able to demonstrate the negligence of a doctor in some cases. ${ }^{3}$ Thus, the court may apply res ipsa loquitur which

${ }^{1}$ Nicholas J. McBride and Roderick Bagshaw, Tort Law, (3 ${ }^{\text {rd }}$ ed, Pearson Longman, Harlow, 2008), p. 239.

${ }^{2}$ Kuwaiti Supreme Court, Case No 17/2001 dated 29/04/2002.

${ }^{3}$ Ibrahim Aldosoki, Supra n. 57, p. 132. 
means that 'the thing speaks for itself'. The court may infer that the doctor was negligent without hearing full evidence from the patient as to what the doctor did or did not do. ${ }^{1}$ However, such a maxim is merely a simple indication and it can be rebutted by the doctor. ${ }^{2}$

If damage to the patient would not have happened "but for" the doctor's negligence then the negligence is a cause of the damage. It is not essentially the cause because there may well be other cases which are causally related. ${ }^{3}$

A res ipsa loquitur argument will be available to assist in verifying that the doctor has breached a duty of care imposed to the patient if ${ }^{4}$ :

${ }^{1}$ John Cooke, Supra n. 78, p.137. Nicholas J. McBride and Roderick Bagshaw, Supra n. 152, p. 240.

${ }^{2}$ Nicholas J. McBride and Roderick Bagshaw, Ibid, p. 240.

${ }^{3}$ Barnett v Chelsea and Kensington Hospital Management Committee [1968] 1 All E.R. 1068, Where there were three nightwatchmen went to hospital after they have been vomiting. The nurse called the casually doctor who told her that they should go home and see their own doctor and he does not need to see them. Five hours later one of them passed away because of poisoning. The "but for" test can be applied to doctor's negligence in this case.

${ }^{4}$ John Cooke, Supra n. 78, p.138. Nicholas J. McBride and Roderick Bagshaw, Supra n. 152 , p. 240 
1- The thing causing the damage was under the exclusive control of the doctor.

This means that the damage which the patient suffers from, could not happen without the negligence of the doctor. The courts have been free in their interpretation of the doctor's control. ${ }^{1}$

2- The damage must be of the sort that does not happen in the absence of negligence. The damage which the patient suffers from cannot occur in normal events without the negligence of the doctor. ${ }^{2}$

3- There must be no explanation for the damage. Only where there is no explanation for the damage can the res ipsa loquitur be available. If all the details of the damage were known, the court could infer whether or not there was negligence on the part of the doctor. ${ }^{3}$

${ }^{1}$ Gee v Metropolitan Railway 91873) LR 8 QB 161; Easson v London \& North Eastern Railway [1944] 1 KB 421.

${ }^{2}$ Mahon v Osborne [1939] 2 KB 14.

${ }^{3}$ Barkway v South Wales Transport Co Ltd [1950] 1 All ER 392. 
The evidential burden of proof shifts to the doctor as soon as the patient has successfully drawn res ipsa loquitur. The doctor must remove the inference of negligence by verifying that he was not negligent. ${ }^{1}$

The patient must commence a legal action against a doctor who caused negligently damage to him within the period of limitation which three years from either the harmful event or when the harmful effects first become noticeable to the patient. ${ }^{2}$ Similarly, in Kuwaiti law, ${ }^{3}$ the legal action must be commenced by the patient within the period of limitation which three years from the first day of effects become noticeable to the patient, or fifteen years of an illegal act, whichever expires first.

In Kuwaiti law, the causal relationship between fault and damage is assumed. The claimant is not obliged to prove it, but the doctor is obliged to prove that the causal relationship does not exist. Therefore, the burden of proof of the causal relationship rests on

${ }^{1}$ Henderson v H E Jenkins \& Sons [1970] AC 282. John Cooke, Supra n. 78, p.140-141.

${ }^{2}$ The Limitation Act 1980, s 14.

${ }^{3}$ Kuwaiti Civil Law, s 253. 
the doctor ${ }^{1}$, who cannot avoid liability unless he proves that the non-performance or delay in performance is due to a foreign cause beyond his control. ${ }^{2}$

\section{Conclusion}

It can be concluded form above that the liability of the doctor can be contractual liability, in the case of existence of contract between the doctor and the patient, or negligence. In the application of the contractual liability, the English law does not require existence the causation between the damage and the fault to establish the liability. The contractual fault of doctor is only sufficient to establish the contractual liability of the doctor. However, the liability of negligence, the English law requires an existence of the causation between the doctor's fault and the damage to establish the liability of negligence. Kuwaiti law requires, whether in contractual liability or negligence, an existence of causation between doctor's fault and the damage to establish the liability. The duty of doctor is to have reasonable degree of proficiency and apply that proficiency with a reasonable level of

${ }^{1}$ Kuwaiti Supreme Court, Case No. 854/2010 dated 13/02/2012.

${ }^{2}$ Article 293 of Kuwaiti Civil Law. Adnan Amkhan, Supra n 39, p175-176. 
prudence when he exercises his work. He is not required to achieve a result.

It can be noted that Kuwaiti law does not devote a separate section to the treatment of doctor liability. Kuwaiti law just left it to the general provisions of the Civil Law. It is recommended if Kuwaiti law devotes specific provisions to address the doctor liability. 